\title{
ПЕРЕДУМОВИ ОПТИМІЗАЦІЇ УПРАВЛІННЯ ЧАСОМ
}

\section{PREREQUISITIES OF TIME-MANAGEMENT OPTIMIZATION}

\author{
Грінченко Раїса Володимирівна \\ доктор економічних наук, доцент, \\ Одеський національний економічний університет \\ ORCID: https://orcid.org/0000-0002-3366-6154
}

\author{
Hrinchenko Raisa \\ Odessa National Economic University
}

\begin{abstract}
У статті обґрунтовано необхідність управління часом для особистості та для підприємства. Виявлено основні категорії суб'єктів, яким необхідно опановувати засади оптимізації управління часом. Простежено ретроспективу теоретичних підходів управління часом. Виділено основні елементи системи управління часом: фрілософрія, стратегія, технологія та ефективність. Запропоновані основні елементи управління часом, такі як: цілепокладання, пріорітезація, фрормування переліку задач, планування та оптимізація задач, виконання задач, контроль за виконанням задач, зворотній зв'язок із цілепокладанням. Розглянуто сутність та особливості оптимізації управління часом. Запропоновано методику застосування методів математичного моделювання вибору альтернативних варіантів при оптимізації управління часом проводити в трьох основних послідовних етапах. Сорормований алгоритм розробки елементів організаційно-практичного забезпечення оптимізації управління часом.

Ключові слова: час, управління часом, оптимізація, алгоритм, методика.
\end{abstract}

В статье обоснована необходимость управления временем для личности и для предприятия. Выявлены основные категории субъектов, которым необходимо овладевать основы оптимизации управления временем. Прослежено ретроспективу теоретических подходов управления временем. Выделены основные элементы системы управления временем: фрилософрия, стратегия, технология и эффрективность. Предложены основные элементы управления временем, такие как: целеполагание, приоритезация, формирование перечня задач, планирование и оптимизация задач, выполнение задач, контроль за выполнением задач, обратная связь с целеполаганием. Рассмотрены сущность и особенности оптимизации управления временем. Предложена методика применения методов математического моделирования выбора альтернативных вариантов при оптимизации управления временем на основании проведения трех основных последовательных этапах. Сформирован алгоритм разработки элементов организационно-практического обеспечения оптимизации управления временем.

Ключевые слова: время, управление временем, оптимизация, алгоритм, методика.

A person has a limited non-renewable resource, the effective use of which is extremely important for any person. Therefore, the issue of optimizing time management as an enterprise, technology and personality is relevant. The theoretical basis for optimizing time-management today should be based on a thorough understanding of the essence of time-management and the main tools for its optimization for the needs of individuals and enterprises. The article highlights the need of management for the individual and for the enterprise. The main categories of subjects who need to master the basics of time management optimization are identified. A retrospective of theoretical approaches to time-management is traced. The main elements of the time-management system are identified: philosophy, strategy, technology and efficiency. The main elements of time-management are proposed, such as: goal setting, prioritization, task list formation, task planning and optimization, task execution, task control, feedback with goal setting. The essence and features of time-management optimization are considered. The technique of application of methods of mathematical modeling of a choice of alternative variants at optimization of time management to spend in three basic consecutive stages is offered. The algorithm of development of elements of organizational and practical maintenance of time-management optimization is formed. Methods of mathematical modeling allow companies in a very limited time with the use of small resources to get answers to complex questions. The formation of the unit for assessing the prerequisites for optimizing time management should be carried out in three main stages: analysis and evaluation of information on tasks and time for their implementation by empirical and statistical methods; data modeling to identify projected trends and directions of development of system components; time-management optimization. All tasks and limitations in the use of such methods must be clearly set and take into account the achievements of the previous stages of formation of the time management system.

Keywords: time, time-management, optimization, algorithm, method. 
Постановка проблеми. Будь-яка людина має у своєму розпорядженні час. Проте період житя у кожного різний. Тільки від особистості залежить, яким чином вона використає наявний у її розпорядженні час. Час - це єдиний ресурс, який ми не можемо повернути, використати пізніше або якимсь чином його змінити. Перед ним усі рівні. Його неможливо зберігати, купити або отримати у подарунок, проте можна вкрасти ваш час на завдання, які вам не потрібні.

Цікавою $€$ точка зору Г. Архангельського: «...час - це один з трьох параметрів за якими можна конкурувати. Інші два - це гроші та якість» $[1$, с. 12]. Тут неможливо не погодитись із такою думкою, проте конкуренція за гроші та якість $€$ стандартною та гарно застосовуємою в сучасному світі, а можливості управління часом особистості або ж підприємства підкорюються не всім.

Ще однією проблемою для більшості людей виступає нерозуміння механізмів часу, невміння використовувати його та керувати, навіть, на найнижчому рівні. Деякі люди живуть у минулому, переносячи минулі події у своє майбутнє. Деякі, навпаки, живуть тільки майбутнім, завжди щось очікують та кудись поспішають. Нi ті, ні інші не отримують задоволення від власного життя, тому що не вміють насолоджуватись поточним моментом та управляти своїм часом у дійсності. Слід навчитись бачити безперервність часу: від минулого часу - теперішній час - до майбутнього часу. Вміння бачити, аналізувати свій час та управляти ним $€$ однією із головних запорук успіху людини.

Таким чином, людина має у своєму розпорядженні обмежений невідновлювальний ресурс, ефективне використання якого має надзвичайне значення для будь-якої людини. Тому актуальним виступає питання оптимізації управління часом, як підприємства, тік і особистості.

Аналіз останніх досліджень і публікацій. В останні роки багато зарубіжних та вітчизняних вчених приділяють значну увагу питанням управління часом. Питання управління часом та його оптимізації на досліджували такі вчені та практики, найбільш відомими 3 яких на сучасному етапі є: Архангельський Г., Аллен Д., Зайверт Л., Кові С., Трейсі Б., Хілл Н. та інші [1-6]. Проте теоретичний базис оптимізації управління часом сьогодні повинен базуватись на досконалому розумінні сутності управління часом та основних інструментів його оптимізації для потреб особистості та підприємств.

Виділення не вирішених раніше частин загальної проблеми. Формування інструментарію управління часом повинно базуватись на досконалому аналізі можливих варіантів оптимізації управління часом та із виділенням їх взаємозв'язків, необхідно дослідити та систематизувати сутнісні характеристики та відмінності існуючого інструментарію управління часом для підприємств та особистості.

Метою статті виступає дослідження теоретичних засад оптимізації управління часом, виділення особливостей інструментарію оптимізації управління часом для підприємств та особистості.

Виклад основного матеріалу. Останнім часом питання ефективного управління часом набувають все більшої популярності у зв'язку із динамічністю та невизначеністю умов життя людини у сучасному світі. Все біль затребуваними стають компетентності, які надають можливості ефективно використовувати час на особистому, колективному або корпоративному рівнях. Саме в цьому й полягає головне завдання управління часом або тайм-менеджменту - пошук та застосування ефективних технологій управління часом.

Розвиток управління часом як окремого напрямку управління розпочався в Голландії та швидко набрав оберти по всьому світі. Однією із визначних подій є вихід книги Лотара Зайверта «Ваш час - у ваших руках» [3, с. 10], яку, насправді, можна вважати першою глибокою працею $з$ питань управління часом. Сьогодні питання управління часом $€$ дуже популярними, про що свідчить безліч публікацій та книг на цю тему.

Наявність великої кількості літератури 3 означеного питання ще не означає спроможність людини ефективно використовувати свій час. У питаннях управління часом особистості велике значення має не тільки теоретична підготовка, а й щоденне практичне застосування отриманої інфрормації та навичок управління часом.

Кому потрібно вивчення основ управління часом? Всього можна перелічити три категорії людей, яким необхідно опановувати ці навички $[1$, с. 18]:

1. Люди, у яких постійно не вистачає часу на виконання завдань.

2. Люди, у яких купа часу та вони не розуміють, що з ним робити.

3. Люди, які розуміють, що використання ними часу не $є$ ефрективним.

Тобто, до цих трьох категорій можна віднести все людство. Навички управління часом у сучасному світі потрібні всім. Проте неможливо навчитись досконало управляти своїм часом. Постійно виникають нові технології та інструменти. 
Управління часом - перманентна діяльність людини протягом всього життя. Причому вдосконалювати свої навички управління часом треба також перманентно протягом всього життя.

Досягнення успіху в житті людини та у діяльності підприємства прямо пропорційно пов'язане із застосуванням основ управління часом. Ефрективне управління часом скорочує його непродуктивні витрати та спрямовує час у продуктивні напрямки, що сприяє досягненню успіху людиною чи підприємством.

Більшість людей при виникненні думок про управління часом вважають, що це кропітка рутинна робота по плануванню, виконанню та знову плануванню. Проте управління часом не зводиться тільки до цих фуннкцій.

Сучасний тайм-менеджмент (управління часом) - це комплексна система управління особистістю та її діяльністю.

Система управління часом базується на основних чотирьох засадах-питанях:

- Філософрія (Навіщо?) - то найголовніше питання, яке задає собі людина, навіщо мені управляти своїм часом?

- Стратегія (Куди?) - визначення свої цілей та напрямів руху.

- Технологія (Що?) - яким чином ми можемо досягти запланованого, які технології та інструменти використовувати?

- Еорективність (Як?) - яким чином краще використовувати ресурси часу?

У бідь-якому разі система управління часом для будь-якої людини є різною: у кожного своя фрілософрія та стратегія, технології, що використовуються та інструменти, що підвищують ефрективність. Тому управління часом - це індивідуальний процес, який повинен здійснюватись кожною людиною окремо, не треба шукати стандартів та загальних методик.

На початковому етапі треба зрозуміти, отримати власну мотивацію для впровадження елементів управління часом в особисте життя та діяльність підприємства, а надалі - це всьго-навсього справа техніки.

Основні елементи управління часом можна представити в такому вигляді:

1. Цілепокладання - виявлення особистих цінностей та цілей, яких хоче досягти людина або підприємство. На етапі цілепокладання необхідно чітко визначитись із цінностями особистості або підприємства, на основі яких необхідно формулювати цілі. Встановлення цілей без урахування цінностей може стати перешкодою для її подальшої реалізації та значно знижується мотивація для досягнення таких цілей. Встановлення цільових показників $є$ одним із обов'язкових етапів оптимізації управління часом. Неможливо оптимізувати час, не маючи цільові показники. Проте будь-які цільові показники у діяльності людини або підприємства повинні відповідати SMART-критеріям, тобто вони повинні бути конкретними, вимірюваними, досяжними, реалістичними та обмеженими у часі.

2. Пріоритезація - визначення пріоритетів у своїх цілях. Сучасна теорія управління часом пропонує велику кількість інструментів пріоритезації цілей особистості чи підприємства. Незважаючи на особливості викристовуємих на цьому етапі інструментів, основне його завдання визначення послідовності та важливості досягнення цілей для людини чи підприємства. Для особистості доцільно пріоритезувати цілі за основним чотирма напрямками розвитку: фрізичне здоров'я та краса, бізнес та кар'єра, соціальні взаємовідносини та саморозвиток особистості. Для підприємства цілі можна розподілити на довгострокові та короткострокові.

3. Формування переліку задач. У розрізі кожної поставленої цілі необхідно сфрормулювати перелік необхідних до виконання завдань, проранжувати їх пріоритетність, відмітити наявні ресурси та напрями вирішення поставлених завдань.

4. Планування та оптимізація задач. Цікавими методиками планування виконання завдань виступає Матриця Ейзенхауера та застосування правила Парето, та інші. Основним інструментом оптимізації при управлінні часом найчастіше виступає сценарне моделювання.

5. Виконання задач.

6. Контроль за виконанням задач.

7. Зворотній зв'язок із цілепокладанням.

Такий алгоритм при управлінні часом надає можливості чітко відстежувати просування по виконанню цілей особистості або підприємства та швидко знаходити «вузькі» місця такого управління.

Розглянемо більш детально сутність та особливості оптимізації управління часом. Розглядаючи визначення сутності поняття «оптимізація», слід звернутись до математичної та економічної точок зору науковців.

3 математичної точки зору під «оптимізацією» розуміють знаходження екстремуму (глобального максимуму або мінімуму), певної функції або вибору найкращого варіанту з безлічі можливих. Тобто основне завдання оптимізації виражене в її визначенні - досягнення цільових показників із урахуванням множини можливих варіантів.

3 економічної точки зору під «оптимізацією» розуміється визначення значень економічних 
показників, при яких досягається оптимум, тобто найкращій стан системи [7, с. 122]. Однією із головних задач при оптимізації управління часом виступає чітке визначення цільових показників.

Під «оптимізацією управління часом» будемо розуміти процес розробки та впровадження заходів із реорганізації використання часу особистістю чи підприємством на основі вибору оптимальних варіантів поведінки.

Тобто фрормування блоку оцінки передумов оптимізації управління часом має здійснюватися у три основні етапи:

- аналіз та оцінка інорормації щодо задач та часу на їх виконання емпіричними і статистичними методами (цілепокладання, пріоритезація, срормулювання задач);

- моделювання даних для виявлення прогнозованих тенденцій і напрямів розвитку компонентів системи (прогнозування із використанням засобів емпіричного та економікоматематичного апаратів ;

- оптимізації управління часом (сценарне моделювання та інші методики).

Методика застосування методів математичного моделювання вибору альтернативних варіантів при оптимізації управління часом полягає в трьох основних послідовних етапах:

1 етап - фрормулювання та побудова математичної моделі завдання, яке необхідно розв'язати. Тобто побудова математичної моделі вибору альтернативних варіантів при оптимізації управління часом. Причому така математична модель повинна враховувати всі необхідні особистості/підприємству обмеження стосовно альтернативних варіантів оптимізації. Тут фрормується реалізаційна та оціночна моделі варіантів змін. При фрормуванні реалізаційної моделі визначають, що може змінитися в діяльності особистості/підприємства при впровадженні змін. Оціночна ж модель показує, які результати може отримати особистість/підприємство внаслідок впровадження тих чи інших змін. Цей етап орормування математичної моделі насамперед спрямований на виявлення варіантів і результатів впровадження змін для особистості чи на підприємстві.

2 етап - знаходження оптимального варіанту змін для потреб конкретної особистості чи підприємства. Слід зауважити, що універсального принципу оптимальності не існує. Тому для кожної математичної задачі встановлюється свій власний принцип оптимальності, іноді таких принципів оптимальності може бути декілька. Чим складніше розв'язувана задача, тим більше принципів оптимальності може бути. Надалі знаходження оптималь- ного рішення досить просто вирішується математичними засобами. Тому при використанні декількох принципів оптимальності підприємство може отримати й декілька варіантів оптимальних рівень розв'язуваної задачі.

3 етап - аналіз отриманих при застосуванні методів математичного моделювання варіантів змін і подальший зворотній зв'язок з компонентами управління часом. При аналізі отриманих таким чином варіантів змін може статися ситуація, коли розраховане оптимальне рішення не співпадає з основними завданнями управління часом, або неприйнятне для особистості/підприємства з будь-яких інших причин. У такому разі може бути обрано інше оптимальне рішення, якщо воно є, або ж повністю змінено принцип оптимальності для поставленого завдання.

Будь-яка система аналізу й оцінки передумов оптимізації управління часом сама по собі не потрібна особистості/підприємству. Наявність аналізу й оцінки передумов оптимізації управління часом не надає підприємству ніяких переваг на ринку. Лише поєднання результатів аналізу й оцінки передумов із подальшою оптимізацією бізнес-процесів підприємства створюють для підприємства переваги.

Слід окремо підкреслити можливості сценарного моделювання. Сценарне моделювання виступає одним із найросповсюдженіших інструментів аналізу та прогнозування даних. Основною перевагою цього методу виступає можливість отримання багатоваріантного прогнозу та прорахування елементів, які відображають рух системи при тому чи іншому варіанті.

Основними етапами сценарного моделювання виступають:

1) визначення ключових питань/завдань. При управлінні часом такі ключові завдання визначають за кожним із цільових блоків;

2) фрормулювання ключових чинників, що впливають на елементи управління часом;

3) ранжування ключових чинників, які можуть викликати зміни, за рівнем важливості для особистості/підприємства та рівнем невизначеності;

4) фрормування логіки побудови сценаріїв та очищення сценаріїв від врахування зайвих чинників;

5) розроблення висновків і рішень щодо сценарного моделювання окремих компонент управління часом;

6) побудова системи індикаторів, які відображають фрактичний рух за сценаріями та їх можливе відхилення.

Спрощенню процедури сценарного моделювання для підприємств сприяють розро- 
блені програмні продукти, наприклад: «IBM WebSphere Business Modeler», «ARIS Business Perfomance Edition», «1C», «SAP», «Oracle, MS BizTalk Server», «DMS (Lotus, Documentum, Web Sphera)», «CAERWin Process Modeler», «Hyperion Performance Scorecard», «STATISTICA».

Економіко-математичні моделі діяльності підприємств мають бути теоретично та емпірично обґрунтованими. Поєднання кількох підходів до фрормування таких моделей надасть підприємству можливість ссрормувати дійсно ефективну систему управління часом, яка враховуватиме передумови, наявні в середовищі фрункціонування підприємства. Використання теоретично обґрунтованих моделей надає можливість вибору компонентів щодо фрункціонування підприємства та побудови на їх основі емпірично обґрунтованої моделі. Такий підхід надає можливість підприємству комплексно підійти до фрормування оптимізації управління часом, використовуючи світові теоретичні надбання у цій ссрері, та врахувати власні практичні особливості.

Формування бізнес-моделей діяльності підприємств як попереднього етапу оптимізації управління часом підприємства повинно базуватись на досконалому аналізі можливих підходів до фрормування бізнес-моделей, основних їх компонентів, взаємозв'язків, систематизації теоретичних підходів до фрорму- вання бізнес-моделей на підставі використання надбань світової економічної науки.

Висновки та рекомендації. Розробку елементів організаційно-практичного забезпечення оптимізації управління часом доцільно виконувати за наступними етапами:

- аналіз та оцінка чинників, що впливають на діяльність підприємства;

- формування та оцінка бізнес-моделей підприємства;

- планування компонентів та цільових показників оптимізації управління часом;

- організація виконання оптимізації управління часом;

- мотивація персоналу до виконання результатів оптимізації;

- контроль виконання оптимізації;

- аналіз та оцінка ефективності впровадження результатів оптимізації управління часом;

- корегування елементів оптимізації управління часом.

Слід зауважити, що методи математичного моделювання надають можливість підприємствам у досить обмежений час при використанні незначних ресурсів отримати відповіді на складні запитання. Проте всі завдання та обмеження при використанні таких методів мають бути поставлені чітко та враховувати надбання попередніх етапів фрормування системи управління часом.

\section{СПИСОК ВИКОРИСТАНИХ ДЖЕРЕЛ:}

1. Архангельский Г.А. Корпоративный тайм-менеджмент: Энциклопедия решений. Москва : Альпина Паблишер, 2015. 211 с.

2. Аллен Д. Как привести дела в порядок. Искусство продуктивности без стресса. Москва : Манн, Иванов и Фербер, 2015. 416 c.

3. Зайверт Л. Ваше время в ваших руках. Москва : Экономика, 1990. 232 с.

4. Кови С. 7 навыков высокоэффрективных людей. Мощные инструменты развития личности. Москва : Альпина Паблишер, 2015. 396 с.

5. Трейси Б. Тайм-менеджмент. Москва : Манн, Иванов и Фербер, 2016. 305 с.

6. Хилл Н. Думай и богатей. Москва : АСТ, 2015. 384 с.

7. Янковой А.Г. Математико-статистические методы и модели в управлении предприятием. Одесса : ОНЭУ, ротапринт, 2014. 250 с.

\section{REFERENCES:}

1. Arkhangelskij G.A. (2015) Korporativnyj tajm-menedzhment: Encziklopediya reshenij. Moscow: Alpina Pablisher, 211 p. (in Russian)

2. Allen D. (2015) Kak privesti dela v poryadok. Iskusstvo produktivnosti bez stressa. Moscow: Mann, Ivanov $i$ Ferber, 416 p. (in Russian)

3. Zajvert L. (1990) Vashe vremya v vashikh rukakh. Moscow: Ekonomika, 232 p. (in Russian)

4. Kovi S. (2015) 7 navykov vysokoeffektivnykh lyudej. Moshhnye instrumenty razvitiya lichnosti. Moscow: Alpina Pablisher, 396 p. (in Russian)

5. Trejsi B. (2016) Tajm-menedzhment. Moscow: Mann, Ivanov i Ferber, 305 p. (in Russian)

6. Khill N. (2015) Dumaj i bogatej. Moscow: AST, 384 p. (in Russian)

7. Yankovoj A.G. (2014) Matematiko-statisticheskie metody i modeli v upravlenii predpriyatiem. Odessa: ONEU, rotaprint, 250 p. (in Russian) 